\title{
Models of sports student exchange and the role of their support systems
}

\author{
Fatona Suraya $^{1, *(\mathbb{1}}$, Tandiyo Rahayu ${ }^{2}{ }^{(\mathbb{C}}$, Rebecca Alcuizar $^{3}(\mathbb{C}$ \\ Universitas Negeri Semarang, Indonesia ${ }^{1 *, 2}$ \\ Mindanao State University, Philippines ${ }^{3}$
}

Received: 27 February 2021; Accepted 26 April 2021; Published 21 July 2021

Ed 2021; 6(2): 162-173

\begin{abstract}
Establishing student exchange programs is one way for sports science faculty to support the University to be a world-class university. For several years the faculty has been hosting several batches of a sports students exchange (SSE) program that gains interest and benefits for the students and the institution; however, limited studies have been conducted to present information about the program and its support system. This research is conducted to explain and give an overview of the program as well as explore the support system of the program. Three primary data, namely a depth-interview, questionnaire, and documentation, are gathered to explore the SSE program. The participants are lectures, faculty management, and students involved in the SSE in 20182019. The existence of the SSE program was exceedingly influenced by the faculty participation in AUCPESS. A grant from the Dharmasiswa Scholarship that aimed to bolster the exchange of culture and build up the Faculty's International atmosphere was the first booster. However, after the funding stopped, the program ran independently with non-financial support from Rector, faculty management, partner universities, and students. Hence, funding is not a pivotal issue as long as the University and faculty management eager to support the program.
\end{abstract}

Keywords: Students exchange; exchange program; supports system; sports students

https://doi.org/10.25299/sportarea.2021.vol6(2).6500

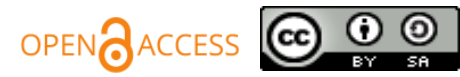

Copyright (C) 2021 Fatona Suraya, Tandiyo Rahayu, Rebecca Alcuizar

Corresponding author: Fatona Suraya, Department of Sports Science, Universitas Negeri Semarang, Semarang, Indonesia Email: suraya@mail.unnes.ac.id

How to Cite: Suraya, F., Rahayu, T., \& Alcuizar, R. (2021). Models of sports student exchange and the role of their support systems. Journal Sport Area, 6(2), 162-173. https://doi.org/10.25299/sportarea.2021.vol6(2).6500

\section{INTRODUCTION}

A student exchange program has been widely popular in universities worldwide (Rabinowitz, 2013), as the program proposes several benefits either for students or for the institution. Research discussed several benefits of student exchange program namely students have the opportunity of learning and embracing themselves with a new language (Berg, 2016; Lin, Del Fabbro, Needham, Sidwell, \& Shaw, 2021); students get social and cultural experiences, students become more multiculturism (Fleckman, Dal Corso, Ramirez, Begalieva, \& Johnson, 2015; O'Brien, Tuohy, Fahy, \& Markey, 2019), getting a new understanding of the country they visited, and building international relationship among students (Berg, 2016; Lin et al., 2021; Wu, Garza, \& Guzman, 2015). Interestingly, students who experience exchange study develop beyond their area of study and able to embrace themselves in an international and intercultural interaction (Chan, Liu, Fung, Tsang, \& Yuen, 2018; Wu et al., 2020). The exchange program is also the best way to become proficient at speaking a foreign language, experience different teaching styles, and build an International Resume (Moody, 2019; Shulsinger, 2017). An International collaboration project is also great in improving 
students' cultural competency skills and basic networking (Chan et al., 2018; Wu, Maddula, Kieff, \& Kunzel, 2020; Wu et al., 2020).

The international students host many benefits for institutions and the country as well. In the United States, International students have contributed nearly $\$ 7$ billion per year for their living costs and school fee, not to mention some goods and souvenirs they bought home (Peterson, Briggs, Dreasher, Dreasher, \& Nelson, 2002; Tas, 2013). Additionally, many international alumni become economic and political leaders who have fond memories and their exchange country and almamater, indirectly influencing the country's bilateral economic and political (Peterson et al., 2002).

It is commonly believed that international education is an activity and programs that promote the transfer of ideas and individual across cultural and international borders and the student exchange programs is the international movement of scholars (Sowa, 2002). Sowa adapted three student exchange programs: total immersion program, protective studies program, and tour model program. The total immersion program positions national students for at least are one semester at a foreign university, usually for one year. This model helps learners take part in academic courses and research the country's language and culture where they live in. The protective studies program offers students a home institution program with resident advisors and instructors, followed by study tours to outline a topic or country. The study run in a shorter period, lasting from about two weeks to a holiday season; "these models are neither mutually exclusive nor in conflict" (Sowa, 2002).

Sports Science Faculty, Universitas Negeri Semarang (UNNES) is one of the Faculty in UNNES, which shows a high commitment to Internationalization (Sihono, 2019). Its internationalization history is closely tied with the history of AUCPESS (ASEAN Universities Conference on Physical Education and Sport Sciences). AUCPESS started in 2011 (Kwanboonchan, 2017). Since July eight, 2014, AUCPESS expanded its scope and upgraded its name to be ACPES (ASEAN Council of Education and Sport) to accommodate many sports' community aspirations and expressions. The first ACPES conference in 2015, was hosted by Universitas Negeri Semarang Indonesia. Nowadays, ACPES has networking eleven universities, namely Kasetsart University Thailand, Chulalongkorn University Thailand, Srinakharinwirot University Thailand, University of Putra Malaysia, Mahasarakham University Thailand, Universitas Negeri Semarang Indonesia, National Institute of Education Singapore, Institute of Technical Education Singapore, Mindanao State University-Iligan Institute of Technology Philippines, Universiti Teknologi MARA Malaysia, and St. Michael's College Singapore. Its member universities managed various activities, namely hosting international conferences, joint research programs, joint publication programs, lecturer exchange programs, student exchange programs, community services, and internship exchange programs, to name but a few.

Upon those many Internationalization programs, one of which is a student exchange program. The student exchange program is a reciprocal activity between two universities or more to exchange students for a certain period. Hinojo_lucena in his research about International collaboration, found that the collaboration between also countries improve learning and relevance for exchange information (Hinojo-Lucena, AznarDíaz, Cáceres-Reche, \& Romero-Rodríguez, 2020). It also teaches different methods and systems in learning specific knowledge (Henderson \& Barker, 2018; Hinojo-Lucena et al., 2020). The Sports Student Exchange Program (SSE) is a program where students from partner universities from sport-related majors come to our faculty and vice versa. The various institutions have offered student exchange programs from traditional schools, universities, some education agents, and government organizations such as AAS, English First, De-Javato, and Fulbright.

However, limited studies have discussed, explain, and explore the student exchange program in Sports Science Faculty. In addition, there is little knowledge on what resources can be used to support these Internationalization programs (Lin et al., 2021). This study aims to fill the gap by exploring the program by answering how the sports students exchange programs run in the sports science faculty of UNNES. This study would give an overview of the implementation of the sports students exchange programs, starting from the history, the sports student exchange models, the program's procedures, purposes, benefits. In addition, the study will also explain the factors that make for the establishment of successful programs. 


\section{METHODS}

This study is an exploratory study conducted by analyzing and interpreting observations about available designs, systems, models, or abstract theories or subjects (Edgar \& Manz, 2017). Social Science Exploratory research is a wide-ranging, purposeful, systematic, pre-arranged activity, according to Stebbins, intended to optimize the discovery of generalizations leading to the explanation and interpretation of a social or psychological field of life. Depending on the point of view taken, a such exploration is a distinctive form of performing research, a scientific methodology, a particular methodological approach (as opposed to confirmation), and the explorer's pervasive personal orientation (Stebbins, 2001). This study is primarily an inductive method. Exploratory research observes unique phenomena to identify patterns and arrive at a general theory of behavior, while the experimental process goes from a general theory to an understanding in detail. The focus of exploratory research is on data assessment or analysis, not developing new designs or models (Edgar \& Manz, 2017).

The first focus of exploratory research is the advancement of theory from data, while the second emphasizes methodology and the actual processing of data by which this development is achieved (Denzin \& Lincoln, 2018). It is argued that researchers explore when they have little to no empirical knowledge of the community, mechanism, behavior, or situation they want to investigate in the exploratory analysis but still have reason to believe that it contains elements that are worth discovering. They need to approach it with two unique orientations to investigate a given phenomenon successfully: flexibility in searching for data and open-mindedness about where to find it (Stebbins, 2001). The primary objective of exploratory research is to produce inductively generated generalizations about the study group, phase, behavior, or situation being studied (Edgar \& Manz, 2017). Next, the researcher weaves these generalizations into a grounded theory that describes the study object. In part, since it is nomothetical, social science exploration is positivistic; its main objective is to produce reasonable generalizations about a form of community, process, behavior, or situation.

This exploratory research is conducted with three primary data, namely a depth-interview, questionnaire, and documentation. The participants are lectures, faculty management, and students involved in the outbound sports student exchange program. A set of questionnaires was given to 92 students who joined SSE in 2018-2019; however, only 72 students filled the questionnaire, which is equal to $78 \%$ of the total participants. Its due to some of them has graduated and hard to be in contacted. It is known that 7 of them are from the Sports Coaching Department, 13 from the Physical Education department, and 26 each from Sports Science and Public Health department, respectively. This exposure is depicted in Figure 1.

\section{Participants Profile}

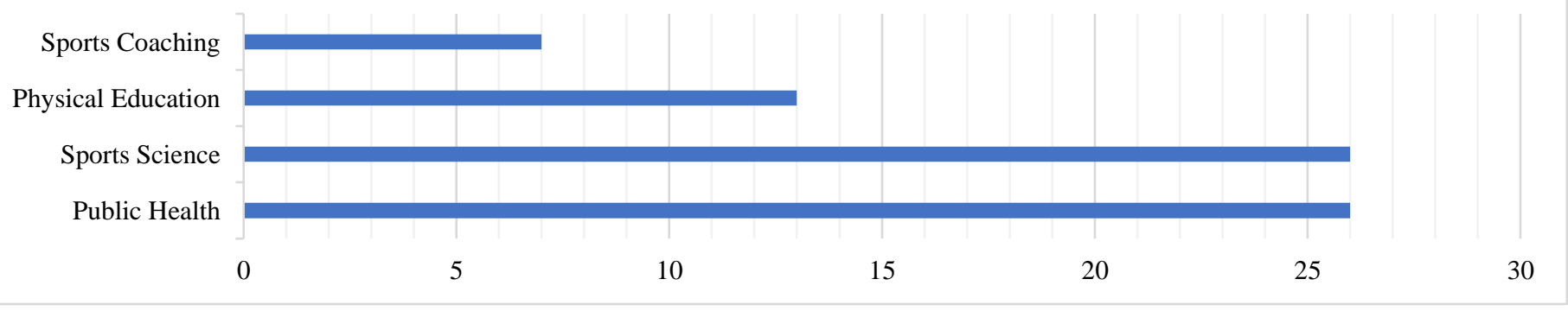

Figure 1. SSE Students' Profile 2018-2019

As the question guiding the study is, how do the sports students exchange programs run in the sports science faculty of UNNES? The researcher sub-divided the question into several sub-questions: history and aims, procedures, and activities. (a) The program's history and aims are answered through an interview with a faculty management representative and a representative of the lecture organizer and supported with documents. (b) The questions about the program's procedures are answered through an interview with two lectures (PIC in 2016-2017 and PIC in 2018-2019) and supported documents. (c) Models of the student 
exchange activities are answered through interviews, questionnaires, and supported documents; the first part of the questionnaire focuses on students' profiles, namely their major, the program they joined, and its duration. Additionally, the next question on the factors that make for the establishment of successful programs or the supports system is answered through an interview with the founding father, the lecturer organizer representative, and the representative of outbound students from the year 2018-2019, and supporting documentation. A depth interview with the program's founding fathers and lecturers involved in the program was conducted following an interview rubric

In analyzing the data, the researcher used Miles and Huberman interactive model analysis. Data analysis came together with data collection following four stages: data gathering and data reducing, data displaying, followed by a final stage on drawing conclusion and verification. In answering the first and second research questions, the interview data with three sources of interviewees were recorded and transcribed. The data were cross-checked with the supportive documents from websites, online news articles, pictures, and email history. After the data were gathered, data that are not related to answer the researched questions were crossed. The related data were presented in writing form and pictures. The themes are used to conclude. In answering the last research question, a questionnaire was spread out to the students besides using interview and supported documents. The data were checked with the interview transcribed and supporting documents from email history, pictures, and news articles. All data which help to answer the questions were display in graph and writing form.

\section{RESULTS AND DISCUSSIONS \\ History and Aims of the Program}

The student exchange program run in the faculty could be divided into two main categories, namely inbound and outbound exchange programs. This type is commonly found in worldwide University Internationalization programs, such as those provided by ISEP, where a home university can exchange with a partner university (ISEP, 2021). The inbound program is a program provided by SSF for international students from partner or non-partner universities who want to have an experience of studying in the SSF. Simultaneously, the outbound is the SSF internationalization program to facilitate students' learning experience abroad as offering students with international viewpoints remains the undertaking of higher education (Carlson et al., 2017). The inbound and outbound program followed are then subdivided into credit and non-credit. This system is linear with the system works in some partner universities such as Srinakhariwirot University and MSU-IIT (IIT, 2020; University, 2020), which have collaborated with UNNES since 2016.

The involvement of sports science faculty in the AUCPESS 2011, which then changed into ACPES in 2015, was the baseline for forming the SSE program (Kwanboonchan, 2017). The SSE program's founding fathers mentioned that the program was initiated after the faculty was actively involved with the AUCPESS, observing other universities that previously hosted student exchange programs. The first SSE program started in 2016 with two MSU IIT students and fully funded by the MSU IIT. It was the first batch of the inbound SSE program of SSF UNNES. Learning from the first experience, the faculty then sends some students abroad to exchange (outbound program). The founding father also suggested that the program is a non-profit program.

Similar questions were asked to a lecturer actively involved in the International division of SSF during 2015-2017. It showed that the SSE program was initiated in early 2015. In contrast to the first interviewee, who mentioned that the program is self-funded and non-profit, the second interviewer explained that minimum funding is the main obstacle to running the program. O'Brien supports this idea that exchange students' programs require high commitment and fully supports (O'Brien et al., 2019). The program, which was designed in 2015, could not run due to a lack of funding. This is in line with Alghamdi's point of view, which stated that funding is a challenge in establishing international exchange (Alghamdi \& Otte, 2016). The first SSE outbound run in 2016, supported by Dharmasiswa funding under University to University / U to $\mathrm{U}$ scheme. Dharmasiswa is a grant program advertised to all universal understudies from nations with a political relationship with Indonesia to ponder the Indonesian dialect (Bahasa Indonesia), culture, and arts 
in Indonesia's 72 colleges. This program was built up in 1974 as a portion of the ASEAN (Association of Southeast Asian Nations) activity, conceding as it were understudies from ASEAN. In any case, in 1976, this program was expanded to assist to other nations. The number of nations interested in this program is more than 185 nations organized by the Ministry of Education and Culture (MoEC), Republic of Indonesia (Kemenlu, 2020). Both interviewees agree that the SSE program started in 2016 with two students from MSU IIT who joined a three-month exchange program (Alcuizar, 2015; IIT, 2020) and then continued with ten students from Thailand (University, 2020) with a shorter duration.

The founding father argues that the SSE program was conducted to support cultural exchange between countries, to give students experiences of studying abroad, and to broader students' point of view of the real world outside of their country so that when later they become a teacher they could share their knowledge and experience with a worldwide perspective to their students. These views are linear with previous research highlighting the exchange program's benefits (Peterson et al., 2002; Moody, 2019; Wu et al., 2020). Research on Intercultural competency development highlight the importance of exchange program to rise students' understanding to diverse cultural worldviews (Richards \& Doorenbos, 2016).

Whereas according to the second interviewee, the SSE program aims to build an English environment in Sports Science Faculty. Thus, the exchange students are invited to sit-in in the classroom and share their experiences in class. By doing so, they will have interaction with lecturers and students to speak in English. Research by Ariyanti supported the idea of English benefits through exchange students, especially an improvement in oral proficiency, pronunciation, and as students interact with others in natural condition using the English language (Ariyanti, 2020).

The study suggested that sports student exchange programs have enriched the class and the faculty's international atmosphere. The Indonesian students who return home after their exchanges can share their experiences in class, and the International students who stay in the class are authentic sources of multiculturalism. This is linear with research that discussed the benefits of international students are a source of diversity on campuses in terms of language and culture, which is increasingly significant and vital (Lin et al., 2021; O'Brien et al., 2019; Wu et al., 2015). Besides, the interaction build between local and international students has developed a sense of understanding among cultures. The international students offer staff and students help to grow their cultural awareness and capacity to work with people from diverse backgrounds (O'Brien et al., 2019; Wu et al., 2015). In line with Wu and O'Brien, Alghamidi argues that an exchange program gives students opportunities for cross-cultural understanding and global awareness for the host institution and domestic and international students (Alghamdi \& Otte, 2016). Thus, the program founding father's idea is in line with the theory raised by $\mathrm{Zu}$ and $\mathrm{Wu}$, an SSE program that is held to support multicultural understanding.

\section{Procedures}

The interview showed that there was no strict procedure for joining the program "We don't give a strict requirement because we aim to invite more students to participate; As long as the students can speak English, have a good academic record, and able to cover the flight tickets, they were likely passed the selection." This is due to the trust build between the institution and the internal selection of the students. However, this case is not happening in some world exchange foundations that incorporate various universities to join, such as AMINEF and ISEP (Aminef, 2020; ISEP, 2020; ISEP, 2021), which professionally conducts and organizes the exchanges. The foundation usually provides a certain eligibility standard, namely, language skill certificate, leadership skill, commitment to the program, reference letter, or any student who applies (Aminef, 2020).

The mechanism was different for the inbound and outbound program. For the inbound program, SSF sends an invitation to partners' universities. The university partner will then conduct the selection program. The selection criteria are based on the students' ability to speak English (interview test), student's Grade Point Average/GPA with a minimum of 3.00, students' motivation, and students' financial statements. The selected students will get a letter of acceptance and invitation letter to apply for a visa. A similar mechanism was applied for the outbound program. After fulfilling the requirements, the students also have to pass an 
interview test. The requirements are relatively improved from year to year. The resume of the requirements are announced in the form of the leaflet as shown in Figure 2 and 3.

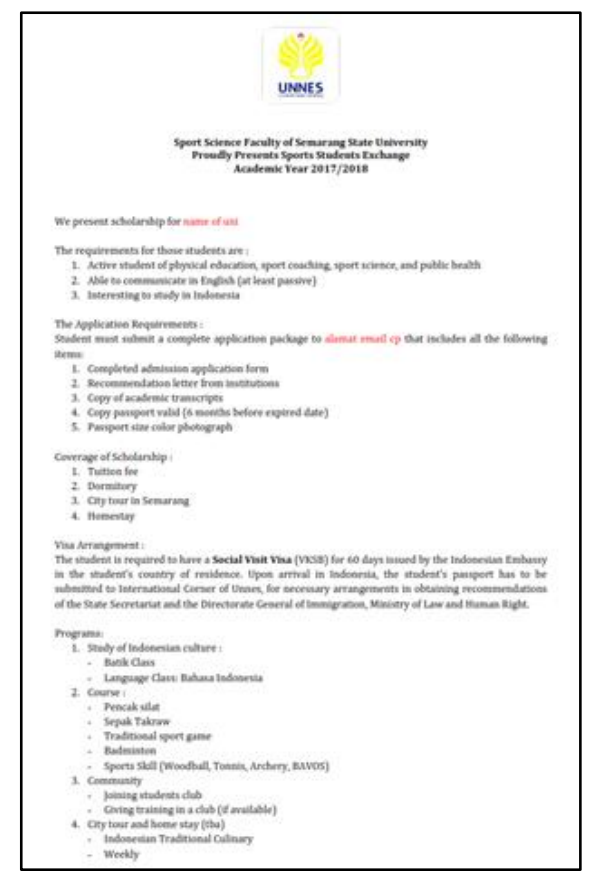

Figure 2. The procedures from the year 2017

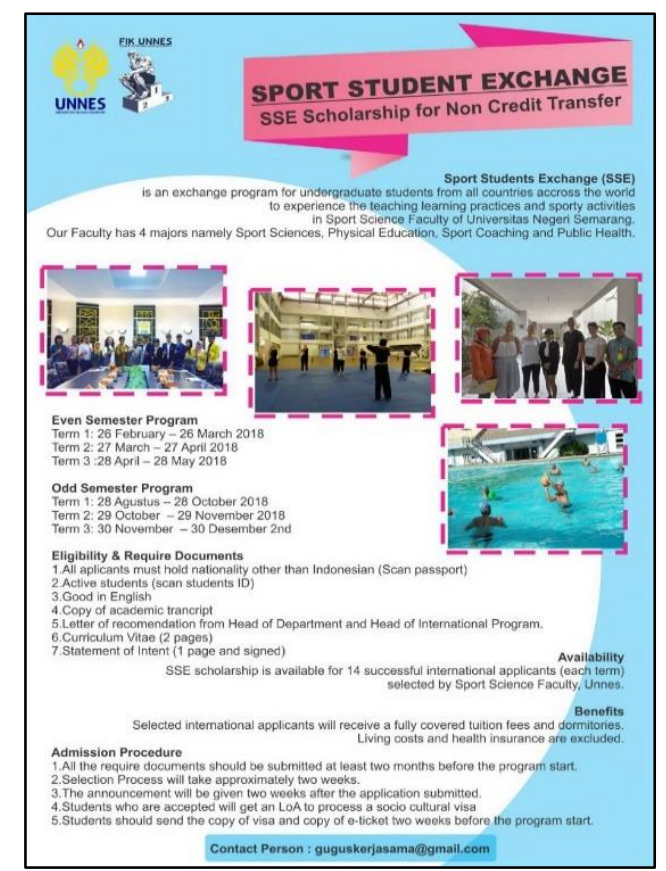

Figure 3. The procedure from the year 2018

In terms of procedure and funding, the study shows no strict procedure for the reciprocal students. It is linear to Fleckman's study, which found no standard procedure for such an exchange program (Fleckman et al., 2015). An interview with the Dean of SSF mentioned that the funding was negotiated through waiving tuition fees between institutions. An interview by Atanasov mentioned that funding was an obstacle for students to join the exchange program; due to the difference in currency, the cost of a semester abroad became higher, which prevented students from taking advantage of an exchange program (Atanasov, 2016). However, the agreement of waiving tuition fees and giving free-dormitory between SSF students and partners university has changed the challenge to become opportunities. Alghamdi argues that the student exchange programs' benefits include financial gain on the institution's part (Alghamdi \& Otte, 2016). This is, however, are not yet been accomplished in the SSE program in SSF. In our institution, the program is a nonprofit program that aims to facilitate students' multicultural experience. Instead of getting some financial profit, the faculty spends some money to support the program. The financial is still become a challenge face by our faculty. Later, a master plan for making the program for profitable income could be made, but profit should not be the priority.

\section{Models}

The sport student exchange models are quite varied from years to years. However, this research focuses only on the outbound program conducted between 2018 and 2019. There are several activities in the outbound program. First and foremost is the Academic Students Exchange; it is two weeks up to a month of exchanges program throughout ASEAN partner university. The second one is KKN Antar Bangsa, or Overseas Community Service; it is a minimum of 2 weeks overseas project with specific missions such as introducing Indonesian sports and culture, promoting conservation, promoting Indonesian arts, and giving health education. The third one is cultural exchanges, which focus on the exchange of culture and languages. The fourth one is KKL or academic field trip; it is a short duration program, lasts from 3 days to a week to explore other countries and experience being in the class (sit-in) of partner universities. The fifth one is PPL or teaching internship; on this occasion, students practice their teaching skills in some overseas schools for a 
minimum of a month. Finally, PKL or internship is where the non-education students have their work experience in some company or organization for a while. The detailed activities and number of students participating from the year 2018 to the year 2019 are shown in Figure 4:

\section{Students Participation}

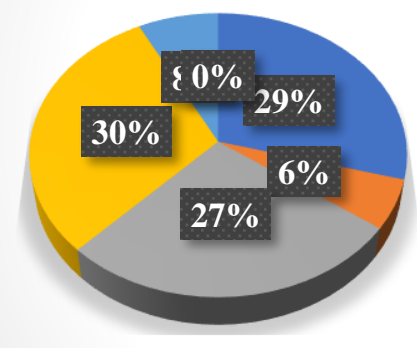

Academic Students Exchange
Cultural Exchange
Community Service
Academic Field Trip
Teaching Practice
Internship

Figure 4. Type of Exchange Program and the Students Participation

Figure 4 explained that the highest participation is in the academic field trip; it is possibly due to shorter duration and lower program cost. The second participation is in Academic Students Exchanges; the faculty had an agreement with some partners university to conduct reciprocal exchanges students; thus, every year, we receive and sent some students. Community service comes third; the Rector policy to accommodate a two-week overseas program as community service is likely motivating the students to join an overseas community service project. Teaching practice is organized by the Center of Profession and Education Development (LPPM), and every year the faculty sends some students to join the program. Cultural exchanges come last, with six students participating, followed by internship which did not run during the year. The internship program was offered to students by the University Malaysia Sabah to practice their work as sports instructors in their hotel. However, the minimum length of the internship is half a year/a semester.

This internship offer was not popular because the students are concerned with their study length, which will add to their domestic school fee cost. In addition, leaving campus for a semester internship will make students miss some courses and require them to take the course later. Awareness of the benefits of internship exchange programs needs to be given so that the students are aware of the benefits of such a program not only for their intraprofessional development but also for their intercultural competencies when engaging with others from socially and linguistically different backgrounds (Henderson \& Barker).

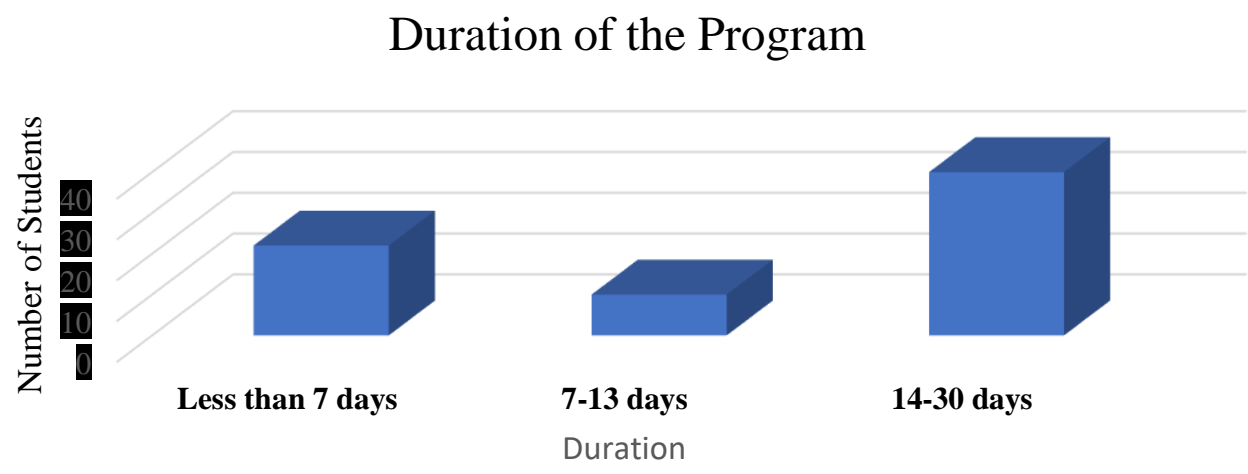

Figure 5. Time Duration of SSE Program

Figure 5. shows that the exchange programs over three types of duration; are less than seven days, seven days to 13 days, and 14 days to a month. Overall, most of the students joined the 14-30 days program with a 
total of 40 students. The next is less than seven days program with 22 students participating, and the last is 7-13 days with only ten students participating.

\section{Number of Program Followed by Students}

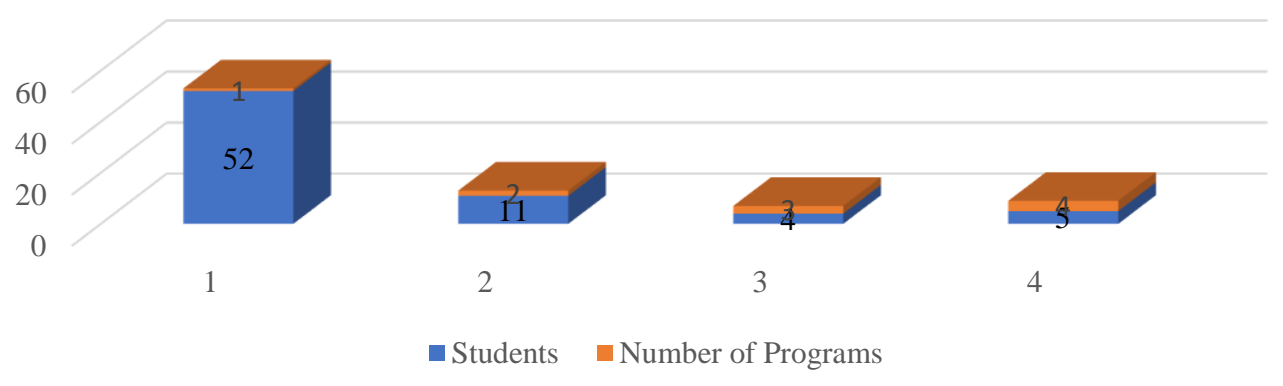

Figure 6. Total number of programs followed by students

Figure 6 illustrates that one student can join up to 4 programs within a year. The students who have experienced studying abroad tend to repeat their experience, as shown in the graphic above. Some students are joining more than one program. Fifty-two students participated in one of the SSE programs, eleven students participated in two programs, four students participated in three programs, and five students in four programs. Details of the types of programs that students participated in are depicted in Figure 5.

An interview with the lecturer who helped organize the event showed that the typical activity in the year of 2016 to 2017 is the students welcomed by their buddies; they got three days of campus orientation, sit-in in several classes, and experience a short homestay. A study by Richards highlighted the benefit of providing pre-departure and host-country orientation to increase students' self-awareness, and cultural openness (Richards \& Doorenbos, 2016). Thus, the inbound and outbound program's orientation program may raise students' sensitivity to have higher intercultural understanding (Chan et al., 2018).

Another interview with the lecturer organizer from the year 2018-2019 mentioned that the activities developed, was adapting what was running previously with some additional activities and choices. In the year 2018, the SSE students were also involved in some students' clubs. After 2019, SSE grew into a credit transfer program with two duration choices: a one-semester program and two-semester programs. The activity started by includes sits in some classes, cultural excursion, and some traditional classes.

In sum, the activities being offered are varied. However, Sowa discussed the total immersion program, which lasts for a semester such program was not applied in the outbound SSE program (Sowa, 2002). Even though an option was given in the form of an overseas internship program, none of the students eager to participate. Interviews were conducted with some students who rejected the offer of overseas internship, "I will miss some classes here and will likely graduate late if I join the internship program.". The students were reluctant to join the program due to there is no system in home university to facilitate them to graduate on time if they take the program; leaving campus for a semester of the internship will also extend their study length, which means they have to pay extra tuition and will be graduated late. In addition, the 6 months internship program will make the students miss some courses. This issue is in contrast to some research which highlighted the benefits of a short-term internship program to enhance learning resources for home and host institution (Lin et al., 2021), improved job prospect, work quality, and development potential as a leader due to the worldwide experience the students got (An et al., 2021). Supports from faculty and university management are needed to facilitate students' need by providing a policy to incorporate the internship exchange program to suit the national curriculum.

Sowa explained that the protective studies model offers program supervision by advisors and educators, followed by some excursion of regional and national culture and history (Sowa, 2002). SSF modified the protective model in programs called academic students exchanges, community service, and teaching practice. The faculty adapts the tour models program (Sowa, 2002) in an academic field trip. 


\section{Support System}

The SSE program needs financial and non-financial support (Atanasov, 2016). Lin argues that supportive environments are key to the learning success of culturally and linguistically diverse students (Lin et al., 2021). The financial supports may come from the government, institutions, and the students themselves. Meanwhile, the non-financial supports come from the institution, faculty management, and partner universities. Other challenges faced by international students are unfamiliarity with the learning method, difficulty with a foreign language, and limited time to adapt (An et al., 2021). O'Brien argues that Intercultural learning requires and strong commitment need careful deliberation of facilitation techniques, planning, support, and curriculum preparation, that reassure actual intercultural learning (Ambrose, Murray, Handoyo, Tunggal, \& Cooling, 2017; O'Brien et al., 2019) the sports science faculty well addresses these issues through providing bilingual classes with bilingual lectures. The language gap is no longer a main issue for inbound and outbound program because there are student buddies who accompany international students during the orientation for at least two weeks.

Discussing the financial support, the second interviewee mentioned that the program was first designed in 2015; however, the program could not run because there is no financial support. This was in line with Bulgaria's case where funding became the biggest obstacle to joining an exchange (Atanasov, 2016). Ambrose also argues that students need robust logistical support to facilitate their learning (Ambrose et al., 2017). Thus, when the Indonesian Government launch Dharmasiswa program. The faculty applied to join the program, and the exchange program could run in 2016 with funding support from the Dharmasiswa program for two years in a row (Kemenlu, 2020). The Dharmasiswa Scholarship was a stimulus for running such a partnership and internationalization program. In 2018, the Dharmasiswa funding support stopped, which forced each institution to run the program independently.

From the year 2018-2019, the program continued with non-financial support from Rector, Dean, Vicedean, head departments, and lecturers. The students support themselves for tickets and living allowance, whereas the faculty negotiate through the University to University agreement (Adminin, 2017). The agreement waived the tuition fee and dormitory fee for both parties. The students are responsible for their living allowance and health insurance. An interview with the Dean of SSF, the program's founding father, mentioned that the program runs with independent funding from each university with the above agreement between universities. In response to the funding, the students give a similar answer: they need to pay only for their living allowance, visa (when needed), and round-trip tickets. The support from partners' universities is entirely various; some give them a free excursion program every weekend, whereas others do not.

Another non-financial support from the university was given to students by Rector regulation number 10 , the year 2017 article 2 number 3 about students' academic awards. It mentioned that students joining two weeks of exchange program are equivalently taking the credits for either community service project, internship, teaching field practice, or two credits of a subject ("Peraturan Rektor UNNES," 2017). Thus, the students joining the exchange program could process the transfer (equivalency of the program) by submitting their exchange program report. This regulation has triggered more students to participate in the SSE program.

It has been contended that International office and academic affairs leaders who are recruiting international students must be delicate to the discernments, needs, and concerns of planned and selected international students, namely their English ability, their financial ability, their choices of courses, the availability for transfer credit program, the availability of the program in promoting mutual intercultural learning, and the fundamental visa law (Chan et al., 2018; Peterson et al., 2002; Tas, 2013). The SSF has addressed these issues by providing some requirements regarding English performance and financial support. Additionally, the faculty also bridge the communication between local students and partner universities regarding their choice to match the course with the local course that the students take. Transfer credit program was still an issue to address, especially related to the similarity of courses offered in both institutions. However, some memorandum of understanding, followed by a memorandum of agreement, and implementation of arrangement with partners university have made this idea closer to implementation. 


\section{CONCLUSION}

The presence of the sports student exchange program in 2016 was highly influenced by support from the Dharmasiswa Scholarship. However, in the year 2018, after the funding stopped, the program could survive and run independently with a non-financial support system from Rector, faculty management, department, partner universities, and students themselves. Thus, funding is not a crucial issue as long as the University and faculty management are willing to support the program. The program being offered varies from an academic program to a cultural exchanges program with a week's duration up to a semester. The short-term program has likely attracted more interest due to its lower cost and shorter duration. The requirement to apply for the programs is quite lenient, which concerns the students' ability to survive in the partner university, such as good English skills, good academic performance, and financial strength. The programs aimed to support the exchange of culture and build up the International atmosphere in the faculty. Students who have experience studying abroad tend to desire to repeat their experience, shown by their participation in more than one program. University, partners university, faculty management, lectures, and the SSE program students are perfect combinations of the program's support system. This study, however, involving only students from the years 2018 and 2019. Tracing early and latest SSE students would host a broader perspective and better results.

\section{REFERENCES}

Adminin. (2017). Farewell Party SSE Program Batch VIII - FIK " Kebersamaan antar Bangsa". Retrieved from https://fik.unnes.ac.id/2017/05/31/farewell-party-sse-program-batch-viii-fik-kebersamaanantar-bangsa/

Alcuizar, R. (2015). PE students in Indonesia for Scholarship Program. Retrieved from https://www.msuiit.edu.ph/news/news-detail.php?id=639

Alghamdi, H., \& Otte, S. (2016). The Challenges and Benefits of Study Abroad. International Journal of Humanities and Social Science, 6(5), 16-22.

Ambrose, M., Murray, L., Handoyo, N. E., Tunggal, D., \& Cooling, N. (2017). Learning global health: a pilot study of an online collaborative intercultural peer group activity involving medical students in Australia and Indonesia. BMC Medical Education, 17(1), 1-11. https://doi.org/10.1186/s12909-0160851-6

Aminef. (2020). Grants and Procedures for Indonesian Fulbright Program. Retrieved from https://www.aminef.or.id/grants-for-indonesians/fulbright-programs/.

An, B., Bae, S., Yang, S. J., Bae, S.-H., Ha, J., \& Rhee, H.-y. (2021). The challenges and achievements of graduates of the nurse bridging program in Cambodia: A qualitative study. Nurse Educ Today, 97, 104714. https://doi.org/10.1016/j.nedt.2020.104714

Ariyanti, A. (2020). EFL Students' English Language Development: In Participation of International Exchange Program. IJELTAL (Indonesian Journal of English Language Teaching and Applied Linguistics), 4, 309-319. https://doi.org/10.21093/ijeltal.v4i2.492

Atanasov, D. (2016). The barriers to global exchange. Retrieved from https://www.universityworldnews.com/post.php?story=20160413194537800.

Berg, V. (2016). Does International Student Exchange Contribute to Educating Teachers We Need in a Multicultural Society? Intercultural Communications In Educational Settings, 3(2), 1-15. 
Carlson, E., Stenberg, M., Chan, B., Ho, S., Lai, T., Wong, A., \& Chan, E. A. (2017). Nursing as universal and recognisable: Nursing students'perceptions of learning outcomes from intercultural peer learning webinars: A qualitative study. Nurse Educ Today, 57, 54-59. https://doi.org/10.1016/j.nedt.2017.07.006

Chan, E. A., Liu, J. Y. W., Fung, K. H. K., Tsang, P. L., \& Yuen, J. (2018). Pre-departure preparation and co-curricular activities for Students' intercultural exchange: A mixed-methods study. Nurse Educ Today, 63, 43-49. https://doi.org/10.1016/j.nedt.2018.01.020

Denzin, N. K., \& Lincoln, Y. S. (2018). The SAGE Handbook of Qualitative Research. United States of America: SAGE Publications, Inc.

Edgar, T. W., \& Manz, D. O. (2017). Chapter 4 - Exploratory Study. Research Methods for Cyber Security, 95-130.

Fleckman, J. M., Dal Corso, M., Ramirez, S., Begalieva, M., \& Johnson, C. C. (2015). Intercultural Competency in Public Health: A Call for Action to Incorporate Training into Public Health Education. Front Public Health, 3, 1-7. https://doi.org/10.3389/fpubh.2015.00210

Henderson, S. A.-O., \& Barker, M. (2018). Developing nurses' intercultural/intraprofessional communication skills using the EXCELLence in Cultural Experiential Learning and Leadership Social Interaction Maps. Journal of clinical nursing, 27(17-18), 3276-3286. https://doi.org/10.1111/jocn.14089

Hinojo-Lucena, F.-J., Aznar-Díaz, I., Cáceres-Reche, M.-P., \& Romero-Rodríguez, J.-M. (2020). Use of social networks for international collaboration among medical students. Educación Médica, 21(2), 137-141. https://doi.org/10.1016/j.edumed.2018.08.009

IIT, M. (2020). MSU IIT List of International Collaboration. Retrieved from https://www.msuiit.edu.ph/about/achievements/collaboration.php.

ISEP. (2020). Study Abroad: Study and live like a local anywhere in the world. Retrieved from https://www.isepstudyabroad.org/programs/study-abroad/.

ISEP. (2021). 2021 ISEP Program Update, Policies, and Covid-19 Information. Retrieved from https://www.isepstudyabroad.org/.

Kemenlu. (2020). Darmasiswa Indonesian Scholarship. Retrieved from https://kemlu.go.id/washington/id/news/4032/darmasiswa-indonesian-scholarship-program20202021.

Kwanboonchan, S. (2017). Welcome Message from President of ACPES. Retrieved from http://acpes2017.kasetsart.org/.

Lin, F. F., Del Fabbro, L., Needham, J., Sidwell, D., \& Shaw, J. (2021). Supporting culturally and linguistically diverse (CALD) undergraduate nursing students undertaking clinical placements in Australia: An exploratory qualitative study of clinical facilitator and CALD student perceptions. Nurse Educ Today, 97, 104712. https://doi.org/10.1016/j.nedt.2020.104712 
Moody, J. (2019). 3 Benefits of Studying Abroad. Retrieved from https://www.usnews.com/education/bestcolleges/articles/2019-03-22/3-benefits-of-studying-abroad.

O'Brien, B., Tuohy, D., Fahy, A., \& Markey, K. (2019). Home students' experiences of intercultural learning: A qualitative descriptive design. Nurse Educ Today, 74, 25-30. https://doi.org/10.1016/j.nedt.2018.12.005

Peraturan Rektor UNNES. (2017). Peraturan Rektor Tentang Pemberian Penghargaan Akademik kepada Mahasiswa Berprestasi Luar Biasa $§ 23$ (2017 23 February 2017).

Peterson, D. M., Briggs, P., Dreasher, L., Dreasher, L., \& Nelson, T. (2002). Contributions of International Students and Programs to Campus Diversity. New Direction for Students Services, 86, 67-77. https://doi.org/10.1002/ss.8609

Rabinowitz, T. (2013). Study Abroad Grows in Popularity, Programs and Places. Colombia College Today, Winter 2016.

Richards, C. A., \& Doorenbos, A. Z. (2016). Intercultural competency development of health professions students during study abroad in India. J Nurs Educ Pract, 6(12), 89-98. https://doi.org/10.5430/jnep.v6n12p89

Shulsinger, T. (2017). 8 Unexpected Benefits to Studying Abroad as a Graduate Student. Retrieved from https://www.northeastern.edu/graduate/blog/study-abroad-benefits/.

Sihono. (2019). 11 Mahasiswa Ilmu Keolahragaan FIK UNNES KKN Antarbangsa di Malaysia. https://unnes.ac.id/berita/11-mahasiswa-ilmu-keolahragaan-fik-unnes-kkn-antarbangsa-dimalaysia.html.

Sowa, P. A. (2002). How Valuable are Students Exchange Programs? https://doi.org/10.1002/he.49

Stebbins, R. A. (2001). Exploratory Research in the Social Sciences. SAGE Publications, Inc. https://doi.org/10.4135/9781412984249

Tas, M. (2013). Promoting Diversity: Recruitment, Selection, Orientation, and Retention of International Students. Journal of International Education and Leadership, 3(2), 1-10.

University, S. (2020). International Programs. Retrieved from https://www.swu.ac.th/en/content/inter_coop.asp.

Wu, A., Noël, G. P. J. C., Wingate, R., Kielstein, H., Sakurai, T., Viranta-Kovanen, S., . . Bernd, P. (2020). An International Partnership of 12 Anatomy Departments - Improving Global Health through Internationalization of Medical Education. Annals of global health, 86(1), 27-27. https://doi.org/10.5334/aogh.2665

Wu, A., Maddula, V., Kieff, M. R., \& Kunzel, C. (2020). An online program to improve international collaboration, intercultural skills, and research knowledge. Journal of Dental Education. 85(S1), 948-951. https://doi.org/10.1002/jdd.12455

Wu, H. P., Garza, E., \& Guzman, N. (2015). International Student's Challenge and Adjustment to College. Education Research International, 2015, 1-9. https://doi.org/10.1155/2015/202753 